\title{
PENGARUH 2-iP, BA, 2,4-D, DAN TDZ PADA EMBRIOGENESIS SOMATIK IN VITRO KOPI ROBUSTA UNGGUL LAMPUNG
}

\section{EFFECTS OF 2-IP, BA, 2,4-D, AND TDZ ON IN VITRO SOMATIC EMBRYOGENESIS OF SUPERIOR ROBUSTA COFFEE CLONE OF LAMPUNG}

\author{
Dwi Hapsoro' $^{1)}$, Dwi Setiawan' ${ }^{2}$, Rahmadyah Hamiranti ${ }^{3}$, Yusnita $^{1}$ \\ ${ }^{1}$ Dosen Jurusan Agroteknologi, Fakultas Pertanian Universitas Lampung \\ ${ }^{2}$ Mahasiswa Agroteknologi, Fakultas Pertanian Universitas Lampung \\ ${ }^{3}$ Mahasiswa Magister Agronomi, Fakultas Pertanian Universitas Lampung \\ Jl. Sumantri Brojonegoro No. 1 Bandar Lampung 35145 \\ Email:dwi.hapsoro@fp.unila.ac.id HP. 081379155175
}

\begin{abstract}
Effects of 2-iP, BA, 2,4-D, and TDZ on In Vitro Somatic Embryogenesis of Superior Robusta Coffee Clone of Lampung. In vitro somatic embryogenesis of Robusta coffee consists of four stages i.e. primary callus induction, embryogenic callus induction, somatic embryo regeneration, and plantlet regeneration. This research aimed to investigate effects of plant growth regulators on primary callus induction in somatic embryogenesis of superior Robusta coffee of Lampung $\mathrm{cv}$. Komari. Leaf explants were cultured on primary callus induction medium supplemented with (mg/l): BA 1; 2-iP 1; 2-iP $1+2,4-\mathrm{D}$ 0,5 ;2-iP 1 + 2,4-D 1 ;TDZ 1 + 2,4-D 0,5; and TDZ $1+2,4-\mathrm{D} 1$ as treatments. The experiment was arranged in a completely randomized design with three repicates, one culture bottles per replication, five explants per bottle. Results of the experiment showed that after 4 weeks in culture all of the treatments resuted in $100 \%$ of primary callus induction, but led to different time of callus initiation and different callus weight. The earliest callus initiation (14.7 days) was acchieved by treatment with 2-iP $1 \mathrm{mg} / \mathrm{l}$, while the latest (16.0-16.3 days) was acchieved by treatment with TDZ + 0.5-1.0 mg/L 2,4$\mathrm{D}$ and BA $1 \mathrm{mg} / \mathrm{l}$. The highest callus fresh weight was acchieved by treatments with 2-iP + 2,4-D (96-110 mg/ explant) while the lowest was with 2-iP only or BA only (24-18 mg/explant). Primary calluses developed to become embryogenic when subcultured to embryogenic callus induction medium. Upon subculture to somatic embryo regeneration medium, the embryogenic calluses developed into somatic embryos.
\end{abstract}

Key Words: Coffea canephora Pierre ex Froe, embriogenic, primary callus, Komari.

\begin{abstract}
ABSTRAK
Pengaruh 2-iP, BA, 2,4-D, dan TDZ pada Embriogenesis Somatik In Vitro Kopi Robusta Unggul Lampung. Embriogenesis somatik in vitro kopi Robusta terdiri dari empat tahap: induksi kalus primer, induksi kalus embriogenik, regenerasi embrio somatik, dan regenerasi planlet. Penelitian bertujuan mempelajari pengaruh zat pengatur tumbuh (ZPT) terhadap pembentukan kalus primer kopi Robusta unggul Lampung klon Komari. Eksplan potongan daun ditanam pada media induksi kalus primer dengan penambahan (mg/1): BA 1;2-iP 1;2-iP 1+2,4-
\end{abstract}


D 0,5 ;2-iP 1 + 2,4-D 1 ;TDZ 1 + 2,4-D 0,5; dan TDZ 1 + 2,4-D 1 sebagai perlakuan. Percobaan menggunakan rancangan acak lengkap dengan tiga ulangan, 3 botol kultur per ulangan, 5 eksplan per botol. Hasil percobaan menunjukkan, pada 4 minggu setelah tanam, semua perlakuan dapat menginduksi kalus primer 100\%, namun waktu terbentuknya kalus pertama kali dan bobot segar kalus primer berbeda-beda. Kalus primer paling cepat terbentuk pada perlakuan 2-iP (14,7 hari setelah tanam), sedangkan paling lambat (16,0-16,3) pada perlakuan $\mathrm{TDZ}+$ 0,5-1,0 mg/L 2,4-D dan BA $1 \mathrm{mg} / \mathrm{l}$. Bobot segar kalus primer tertinggi didapat pada perlakuan 2-iP + 2,4-D (96-110 mg/eksplan) dan terkecil pada perlakuan 2-iP atau BA saja (24-18 mg/eksplan). Kalus primer berkembang menjadi kalus embriogenik waktu dipindah ke media induksi kalus embriogenik. Subkultur kalus embriogenik ke media regenerasi menghasilkan embrio somatik.

Kata kunci: Coffea canephora Pierre ex Froe, embriogenik, kalus primer, Komari.

\section{PENDAHULUAN}

Indonesia adalah negara penghasil kopi keempat terbesar di dunia setelah Brazil, Vietnam dan Kolombia (Worldatlas, 2019). Dalam perdagangan kopi dunia, terdapat dua jenis kopi terpenting yaitu kopi arabika (Coffea arabica L.) dan kopi robusta ( $C$. Canephora Pierre ex Froehner). Pangsa pasar kopi dunia didominasi oleh kopi arabika. Walaupun demikian, proporsi dominasi pasar kopi arabika telah menurun yaitu dari 76,5\% pada tahun 1979 menjadi $57,6 \%$ pada tahun 2013. Hal ini berarti peningkatan pangsa pasar kopi robusta telah mengalami kenaikan dari 23,5\% pada tahun 1979 menjadi 42,4\% pada tahun 2013 (Hartatri et al., 2016). Di Indonesia, budidaya kopi didominasi oleh kopi robusta, yaitu mencapai 85\% dari produksi kopi nasional, dan hanya 15\%-nya kopi arabika (Direktorat Jenderal Perkebunan, 2015).

Budidaya kopi di Indonesia didominasi oleh perkebunan rakyat (95\%) dan sisanya adalah perkebunan besar negara (3\%) dan perkebunan besar swasta (2\%). Rata-rata produktivitas kopi di perkebunan besar di Indonesia pada tahun 2016 diperkirakan $855 \mathrm{~kg}$ /ha untuk perkebunan besar nasional dan $864 \mathrm{~kg} /$ ha untuk perkebunan besar swasta, sedangkan produktivitas rata-rata perkebunan kopi rakyat $722 \mathrm{~kg} / \mathrm{ha}$ (Direktorat Jenderal Perkebunan, 2015). Angka ini jauh lebih rendah dibandingkan dengan rata-rata produktivitas kopi robusta di Brazil, yang mencapai $1800 \mathrm{~kg} / \mathrm{ha}$ (USDA, 2016).

Di antara penyebab rendahnya produktivitas kopi robusta perkebunan rakyat adalah kultur teknis yang kurang intensif, yaitu masalah ketersediaan bibit berkualitas dari klon-klon kopi unggul, pengaturan tata letak penanaman multiklonal kopi robusta yang kompatibel satu sama lain, dan pemeliharaan tanaman yang kurang optimal yang meliputi pemangkasan, pemupukan, pengairan, pengendalian organisme pengganggu tanaman, dan peremajaan tanaman tua yang sudah tidak produktif. Bahan pertanaman yang digunakan pada perkebunan kopi rakyat pada umumnya berasal dari biji. Sifat kopi robusta yang allogamous atau menyerbuk silang menyebabkan tanaman-tanaman yang berasal dari biji mempunyai sifat beragam, walaupun dari pohon indukan yang sama.

Kopi robusta bersifat self-incompatible, 
sehingga pola penanaman multiklonal menggunakan klon-klon unggul yang kompatibel satu sama lain dapat meningkatkan hasil kopi secara signifikan. Oleh karena itu ketersediaan bibit kopi robusta berkualitas dari klon-klon unggul sangat penting untuk menjamin produktivitas tinggi. Perbanyakan klonal kopi secara konvensional umumnya dengan setek batang atau sambung pucuk. Cara-cara tersebut sebenarnya mudah dan murah, namun diperlukan sumber bahan setek dan entress atau batang atas dalam jumlah memadai. Salah satu alternatif perbanyakan klonal secara cepat untuk menghasilkan bibit kopi berkualitas adalah dengan teknik kultur jaringan, yaitu melalui pola regenerasi embriogenesis somatik. Teknik ini dapat menghasilkan bibit yang true-to-type yang seragam dalam jumlah besar dalam waktu relatif singkat (Hapsoro dan Yusnita, 2018).

Keberhasilan embriogenesis somatik in vitro kopi arabika dan robusta telah dilaporkan oleh beberapa peneliti sebelumnya (Hatanaka et al., 1991, Samson et al., 2006 dan Ibrahim et al., 2017). Hatanaka et al. (1991) menyatakan bahwa sitokinin merupakan faktor yang esensial dalam proses embriogenesis somatik kopi robusta dari eksplan daun. Sitokinin yang dapat digunakan untuk menginduksi kalus dan embrio somatik (ES) pada eksplan daun kopi adalah benzyladenine (BA), 2-isopentenyladenine (2-iP), dan thidiazuron (TDZ), sedangkan zat pengatur tumbuh (ZPT) golongan auksin yang sering digunakan sebagai campuran dengan sitokinin adalah 2,4dichlorophenoxyacetic acid (2,4-D). Samson et al. (2006) mendapatkan bahwa 84-100\% eksplan yang dikulturkan pada media yang mengandung sitokinin 2iP $(4,93 \mu \mathrm{M})$ bersama-sama dengan auksin 2,4-D $(2,25 \mu \mathrm{M})$ menghasilkan kalus embriogenik dari eksplan daun kopi robusta dan arabika. Ibrahim et al., (2007) mendapatkan bahwa pemberian TDZ dan 2,4-D secara bersama-sama terbukti efektif untuk menginduksi kalus embriogenik pada eksplan daun kopi Robusta.

Berbagai bukti telah terdokumentasi bahwa respons regenerasi pada kultur in vitro tanaman sangat dipengaruhi oleh genotipe tanaman dan jenis dan konsentrasi ZPT yang terkandung di media kultur (Hapsoro dan Yusnita, 2018). Respons pembentukan kalus dan ES terhadap ZPT sangat dipengaruhi oleh genotipe tanaman yang dikulturkan. Penelitian ini bertujuan untuk mempelajari pengaruh jenis dan konsentrasi ZPT, yang terdiri dari beberapa sitokinin (2-iP, BA atau TDZ) dan auksin 2,4-D terhadap pembentukan kalus primer kopi Robusta unggul Lampung cv. Komari.

\section{METODE PENELITIAN}

\section{Bahan Tanaman}

Penelitian dilakukan dari bulan April 2018 Oktober 2019. Eksplan berupa potongan daun muda (panjang 7-12 cm) kopi Robusta klon 'Komari' dari Lampung, Indonesia. Eksplan dicuci dengan deterjen cair, dibilas dengan air mengalir, direndam dalam larutan fungisida mankozeb $2 \mathrm{~g} / 1$ selama 15 menit, lalu dibilas dengan air mengalir. Eksplan dicelupkan dalam etanol $70 \%$ selama 3 detik lalu dibilas dengan air steril sebanyak tiga kali. Selanjutnya eksplan direndam- 
kocok dalam larutan pemutih komersial $(\mathrm{NaOCl}$ 5,25\%) dengan konsentrasi 10\% selama 7 menit, lalu dibilas dengan air steril sebanyak tiga kali.

\section{Media Kultur}

Media kultur yang digunakan adalah media induksi kalus primer (IKP), media induksi kalus embriogenik (IKE), dan media regenerasi embrio somatik (RES) (Samson et al (2006) (Tabel 1), yang merupakan modifikasi dari media dasar Murashige dan Skoog (1962). Ke dalam media IKP ditambahkan zat pengatur tumbuh (ZPT) sesuai perlakuan. Keasaman media ditetapkan pada $\mathrm{pH}$ 5,8 dengan penambahan $\mathrm{KOH} 1 \mathrm{~N}$ atau $\mathrm{HCl} 1 \mathrm{~N}$. Sebagai pemadat media digunakan $7 \mathrm{~g} / \mathrm{l}$ agar-agar. Media dipanaskan hingga mendidih, lalu dituangkan ke dalam botol-botol kultur (ukuran $250 \mathrm{ml}$ ), $25 \mathrm{ml} /$ botol. Botol ditutup dengan lembaran plastik tahan panas. Media disterilisasi dalam autoklaf pada suhu $121^{\circ} \mathrm{C}$ dan tekanan $1,2 \mathrm{~kg} / \mathrm{cm}^{2}$ selama 15 menit.

\section{Penanaman Eksplan dan Subkultur}

Eksplan berukuran 5 x 5 mm dengan menyertakan bagian tulang daun samping. Eksplan

Tabel 1. Komposisi media induksi kalus primer (IKP), induksi kalus embriogenik (IKE) dan regenerasi embrio somatik berdasarkan Samson et al.(2006).

\begin{tabular}{|c|c|c|c|}
\hline Komponen Media & $\begin{array}{l}\text { Media Induksi Kalus } \\
\text { Primer (IKP) (mg/l) }\end{array}$ & $\begin{array}{l}\text { Media Induksi Kalus } \\
\text { Embriogenik (IKE) (mg/l) }\end{array}$ & $\begin{array}{l}\text { Media Regenerasi Embrio } \\
\text { Somatik (RES) (mg/l) }\end{array}$ \\
\hline $\mathrm{NH}_{4} \mathrm{NO}_{3}$ & 250 & 825 & 825 \\
\hline $\mathrm{KNO}_{3}$ & 400 & 950 & 950 \\
\hline $\mathrm{Ca}\left(\mathrm{NO}_{3}\right)_{2} \cdot 4 \mathrm{H}_{2} \mathrm{O}$ & 300 & - & - \\
\hline $\mathrm{MgSO}_{4} .7 \mathrm{H}_{2} \mathrm{O}$ & 90 & 185 & 185 \\
\hline $\mathrm{KH}_{2} \mathrm{PO}_{4}$ & 85 & 85 & 85 \\
\hline $\mathrm{CaCl}_{2} .2 \mathrm{H}_{2} \mathrm{O}$ & 160 & 220 & 220 \\
\hline $\mathrm{H}_{3} \mathrm{BO}_{3}$ & 3,1 & 3,1 & 3,1 \\
\hline $\mathrm{CuSO}_{4} .5 \mathrm{H}_{2} \mathrm{O}$ & 0,0125 & 0,0125 & 0,0125 \\
\hline $\mathrm{MnSO}_{4} \cdot \mathrm{H}_{2} \mathrm{O}$ & 90,3 & 11,2 & 11,2 \\
\hline $\mathrm{Na}_{2} \mathrm{MoO}_{4} \cdot 2 \mathrm{H}_{2} \mathrm{O}$ & 0,125 & 0,125 & 0,125 \\
\hline $\mathrm{ZnSO}_{4} \cdot 7 \mathrm{H}_{2} \mathrm{O}$ & 4,3 & 4,3 & 4,3 \\
\hline $\mathrm{CoCl}_{2} \cdot 6 \mathrm{H}_{2} \mathrm{O}$ & - & 0,025 & 0,025 \\
\hline $\mathrm{KI}$ & - & 0,83 & 0,83 \\
\hline Tiamin-HCl & 15 & 20 & 10 \\
\hline Asam Nikotinat & 1 & - & 1 \\
\hline Piridoxin & 1 & - & 1 \\
\hline Mio Inositol & 130 & 200 & 200 \\
\hline Glysin & - & 20 & 2 \\
\hline Cystein & - & 40 & - \\
\hline Adenin Sulfat & - & 60 & 40 \\
\hline Kasein Hidrolisat & - & 200 & 400 \\
\hline $\mathrm{FeSO}_{4} .7 \mathrm{H}_{2} \mathrm{O}$ & 27,8 & 27,8 & 27,8 \\
\hline $\mathrm{Na}_{2}$ EDTA & 37,3 & 37,3 & 37,3 \\
\hline Asam Askorbat & 200 & 200 & - \\
\hline Asam Sitrat & 150 & 150 & - \\
\hline Sukrosa & 30000 & 30000 & 35000 \\
\hline BA & Sesuai perlakuan & 4 & - \\
\hline $2,4-\mathrm{D}$ & Sesuai perlakuan & 1 & - \\
\hline TDZ & Sesuai perlakuan & - & - \\
\hline 2-iP & Sesuai perlakuan & - & - \\
\hline Kinetin & - & - & 2 \\
\hline
\end{tabular}


dikulturkan pada media IKP selama 4 minggu, 5 eksplan per botol, dengan permukaan adaksial menempel pada media. Pada akhir minggu ke-4 di media IKP, bobot kalus yang terbentuk dihitung, yang merupakan selisih antara bobot eksplan bersama kalus yang terbentuk dan bobot eksplan sebelum dikulturkan. Eksplan dengan kalus primer ini lalu dikulturkan pada media IKE selama 4 minggu untuk merangsang pembentukan kalus embriogenik. Banyaknya kalus yang berwarna putih, yang akan menghasilkan kalus embriogenik diukur dengan cara skoring (Gambar 1). Kalus disubkultur ke media yang sama untuk merangsang pembentukan dan proliferasi kalus embriogenik. Kultur diinkubasi dalam gelap dalam ruang kultur pada suhu $24 \pm 2^{\circ} \mathrm{C}$. Kalus-kalus embriogenik diseleksi lalu dikulturkan pada media RES untuk regenerasi embrio somatik pada kondisi terang pada suhu $24 \pm 2^{\circ} \mathrm{C}$.

\section{Rancangan Percobaan}

Perlakuan berupa penambahan ZPT ke dalam media IKP, yaitu: (1)BA 1 mg/L; (2) 2-iP 1 mg/ L; (3) 2-iP $1 \mathrm{mg} / \mathrm{L}+2,4-\mathrm{D}$ 0,5 mg/L; (4) 2-iP $1 \mathrm{mg} / \mathrm{L}+$ 2,4-D $1 \mathrm{mg} / \mathrm{L}$; (5) TDZ $1 \mathrm{mg} / \mathrm{L}+2,4-\mathrm{D}$ 0,5 mg/L; dan (6) TDZ $1 \mathrm{mg} / \mathrm{L}+2$,4-D $1 \mathrm{mg} / \mathrm{L}$. Percobaan menggunakan rancangan acak lengkap dengan 3 ulangan. Masing-masing satuan percobaan terdiri atas 3 botol kultur, 5 eksplan/botol. Homogenitas data diuji dengan uji Barlett dan dilanjutkan analisis ragam dengan pemisahan nilai tengah menggunakan uji beda nyata terkecil (BNT) pada taraf 5\%. Variabel yang diamati yaitu waktu terbentuk kalus primer, persentase eksplan berkalus, bobot segar kalus primer, dan skor pembentukan kalus putih. Penentuan skor pembentukan kalus putih dilakukan menurut kriteria yang disajikan pada Gambar 1.

\section{HASIL DAN PEMBAHASAN}

Semua formulasi media induksi kalus primer (IKP) yang diuji menghasilkan persentase eksplan berkalus $100 \%$, namun kecepatan pembentukan dan banyaknya kalus berbeda-beda pada tiap perlakuan. Respons mulai terjadi pada saat eksplan berada pada 12 hari setelah tanam (HST) di media IKP, yang ditandai dengan pembengkakan pada bekas sayatan. Pada media perlakuan BA $1 \mathrm{mg} / 1$ dan 2-iP $1 \mathrm{mg} / 1$, pembengkakan terjadi hanya pada bekas sayatan pada tulang daun, sedangkan pada media yang mengandung
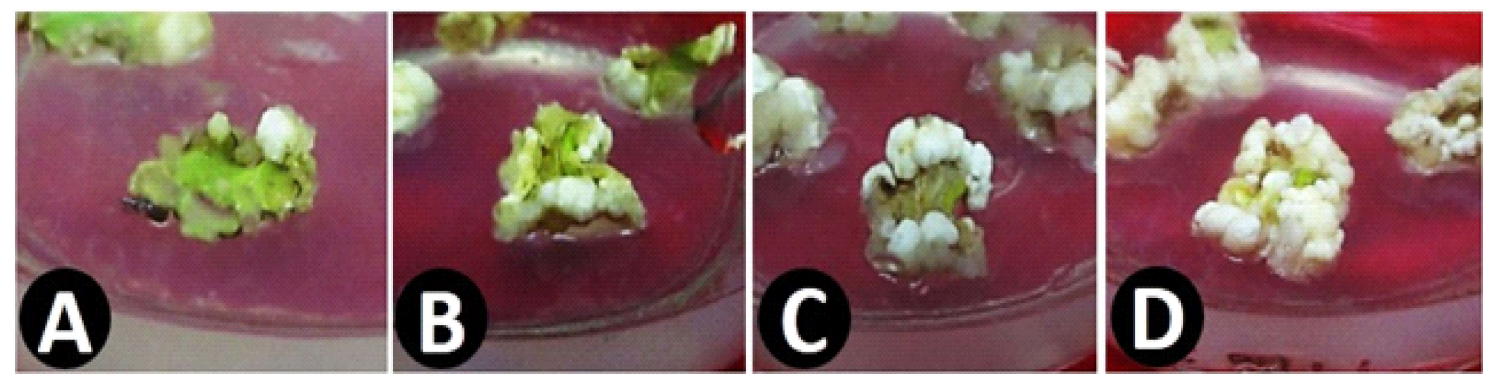

Gambar 1. Skor jumlah kalus warna putih yang terbentuk ditentukan berdasarkan persentase keliling potongan eksplan yang ditumbuhi kalus putih. (a) skor 1 (0-25\%), (b) skor 2 (>25-50\%), (c) skor 3 ( $>50$ $75 \%)$, dan (d) skor 4 (>75\%) 
2,4-D, pembengkakan terjadi pada bekas sayatan pada baik tulang daun maupun bagian daun yang tidak bertulang daun.Pembengkakan lalu diikuti dengan pembentukan kalus. Pembentukan kalus primer pada media yang tidak mengandung 2,4-D utamanya terjadi pada bekas sayatan tulang daun, sedangkan yang mengandung 2,4-D terjadi di seluruh bekas sayatan daun (Gambar 2).

Pembentukan kalus primer tercepat terjadi pada media perlakuan 2-iP $1 \mathrm{mg} / 1$, yaitu 14,67 HST (hari setelah tanam) (Tabel2). Kombinasi dengan2,4D menyebabkan pembentukan kalus primer lebih lambat, yaitu mulai terbentuk pada sekitar 15 HST. Perlakuan lainnya (BA 1 mg/l; TDZ 1 mg/l + 2,4-D 0,5 mg/l; dan TDZ $1 \mathrm{mg} / 1+2,4-\mathrm{D} 1 \mathrm{mg} / \mathrm{l})$ menyebabkan pembentukan kalus primer yang paling lambat, yaitu sekitar 16 HST (Tabel 2). Bobot kalus terbesar dihasilkan oleh eksplan yang dikulturkan pada media perlakuan 2-iP + 2,4-D 1 mg/l (110,1 mg) dan terkecil oleh eksplan yang dikulturkan pada media perlakuan BA $1 \mathrm{mg} / 1$ (18,4 mg). Secara umum, media perlakuan ZPT tunggal menghasilkan bobot kalus primer yang lebih kecil (Tabel 2).

Pada media IKE kalus-kalus yang muncul sebagian berwarna putih, yang dapat berkembang menghasilkan kalus-kalus yang embriogenik. Oleh karena itu berapa banyak kalus putih yang terbentuk pada media IKE menjadi variabel penting. Data pada Tabel 1 menunjukkan bahwa perlakuan media 2-iP 1 $\mathrm{mg} / 1+2,4-\mathrm{D} 1 \mathrm{mg} / \mathrm{l}$ menghasilkan jumlah kalus putih terbanyak, sedangkan yang terrendah dihasilkan oleh media perlakuan TDZ 1 mg/1 + 2,4-D 1 mg/1. Kalus putih disubultur ke media yang sama, yaitu media IKEuntuk merangsang pembentukan kalus embriogenik. Kalus putih mencoklat lalu muncul kalus embriogenik (Gambar 3). Kalus-kalus ini jika disubkultur pada media yang samaakan mengalami proliferasi.Kalus embriogenik ini jika disubkultur ke
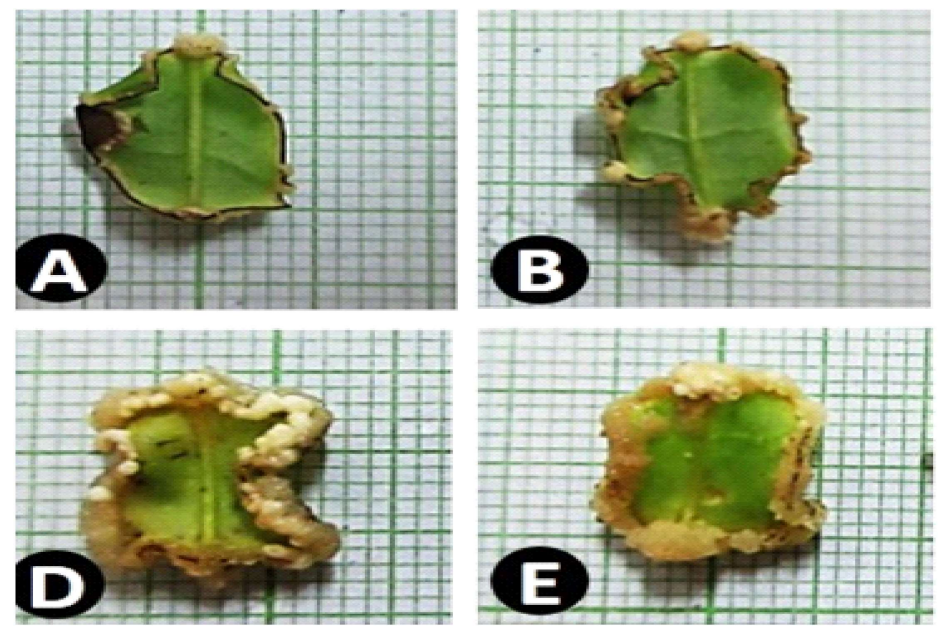
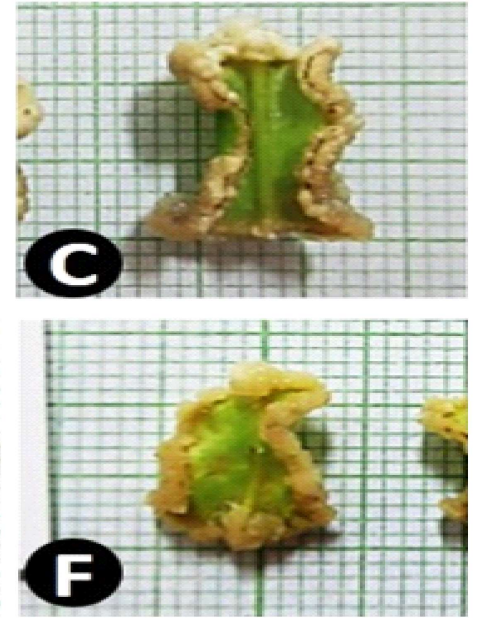

Gambar 2. Pembentukan kalus primer pada eksplan daun kopi Robusta yang dikulturkan in vitroselama 4 minggu di media induksi kalus primer (IKP) dengan berbagai perlakuan jenis dan konsentrasi ZPT (konsentrasi dalam mg/l): (a) BA 1 ; (b) 2-iP 1; (c) 2-iP 1 + 2,4-D 0,5; (d) 2-iP 1 + 2,4-D 1; (e) TDZ $1+2,4-\mathrm{D} 0,5$, dan (f) TDZ $1+2,4-\mathrm{D} 1$. 
Tabel 2. Pengaruh jenis dan konsentrasi ZPT terhadap saat mulai terbentuk kalus, bobot segar kalus, dan jumlah kalus putih pada kultur in vitro tanaman tebu dengan menggunakan potongan daun sebagai eksplan

\begin{tabular}{clccc}
\hline No. & \multicolumn{1}{c}{ Perlakuan } & $\begin{array}{c}\text { Saat mulai terbentuk } \\
\text { kalus (HST) }\end{array}$ & $\begin{array}{c}\text { Bobot segar kalus } \\
\text { pada 4 MST (mg) }\end{array}$ & $\begin{array}{c}\text { Jumlah kalus putih } \\
\text { (Nilai skor) }\end{array}$ \\
\hline 1. & BA 1 mg/l & $16,3 \mathrm{c}$ & $18,4 \mathrm{~d}$ & $1,07 \mathrm{c}$ \\
2. & $2-\mathrm{iP} 1 \mathrm{mg} / \mathrm{l}$ & $14,7 \mathrm{a}$ & $24,0 \mathrm{~d}$ & $1,11 \mathrm{c}$ \\
3. & $2-\mathrm{iP} 1 \mathrm{mg} / \mathrm{l}+2,4-\mathrm{D} 0,5 \mathrm{mg} / 1$ & $15,3 \mathrm{~b}$ & $95,9 \mathrm{a}$ & $2,67 \mathrm{~b}$ \\
4. & $2-\mathrm{iP} 1 \mathrm{mg} / \mathrm{l}+2,4-\mathrm{D} 1 \mathrm{mg} / \mathrm{l}$ & $15,3 \mathrm{~b}$ & $110,1 \mathrm{a}$ & $1,18 \mathrm{c}$ \\
5. & TDZ $1 \mathrm{mg} / 1+2,4-\mathrm{D} 0,5 \mathrm{mg} / 1$ & $16,0 \mathrm{c}$ & $77,7 \mathrm{~b}$ & $1,18 \mathrm{c}$ \\
6. & TDZ 1 mg/l + 2,4-D 1 mg/l & $16,2 \mathrm{c}$ & $56,4 \mathrm{c}$ & $0,42 \mathrm{~d}$ \\
\hline & BNT 0,05 & 0,3 & 17,2 & 0,56 \\
\hline
\end{tabular}

Keterangan: Angka yang diikuti oleh huruf yang sama pada kolom yang sama tidak berbeda nyata menurut ujiBNT0,05 HST = hari setelah tanam; MST= minggu setelah tanam. Bobot segar kalus merupakan selisih antara bobot segar eksplan berkalus pada 4 MST dan bobot eksplan pada saat tanam pada media induksi kalus primer (IKP). Kalus putih adalah kalus pada media induksi kalus embriogenik (IKE), yang berwarna putih tidak transparan yang kemudian menghasilkan kalus embriogenik pada media yang sama. Jumlah kalus putih dinilai dengan skor pada 8 MST atau 4 MST pada media IKE. Nilai skor didasarkan pada kriteria pada Gambar 1.

media regenerasi embrio somatik (RES) selama sedikitnya tiga periode pengulturan, masing-masing berdurasi 4 minggu akan menghasilkan embrio somatik (ES). Gambar 4 menunjukkan ES kopi pada berbagai stadia, yaitu globular $(\mathrm{G})$,heart shaped $(\mathrm{H})$ dan cotiledonary (C). Beberapa SE pada fase cotiledonary berwarna hijau dan mulai berkecambah menjadi tanaman.

Embriogenesis somatik in vitro tanaman dapat dibagi menjadi dua fase, yaitu fase induksi dan fase ekspresi (Arnold, 2008). Pada fase induksi eksplan dirangsang untuk membentuk kalus embriogenik, yaitu kalus yang terdiri atas sel-sel yang mempunyai kemampuan untuk membentuk embrio somatik. Kalus embriogenik dapat membelah-belah diri, terus tumbuh menjadi semakin banyak dengan tetap mempertahankan sifat embriogeniknya. Pada fase ekspresi kalus embriogenik ini berkembang menjadi embrio yang siap untuk berkecambah. Pada tanaman kopi, perbanyakan melalui embriogenesis somatik menggunakan tahap-tahap sebagai berikut: induksi kalus primer, induksi kalus embriogenik, regenerasi atau pembentukan embrio, dan regenerasi tanaman dari embrio (Samson et al., 2006; Ducos et al., 2007). Pada penelitian ini, tahapan utuh tersebut belum semuanya dilalui. Pada penelitian ini tahapan yang dilalui adalah baru sampai pada regenerasi embrio pada media regenerasi embrio somatik(RES). Dalam hal ini semua kalus putih hasil induksi pada media induksi kalus primer (IKP) dapat menghasilkan kalus embriogenik pada waktu disubkultur pada media induksi kalus embriogenik (IKE) (Gambar 3). Berdasarkan pada penampakan luar, kalus embriogenik dicirikan oleh warnanya yang kuning, friable, dan tersusun dalam dompolan (Campos et al., 2017)

Seperti yang terjadi pada umumnya tanaman lain, pembentukan kalus diawali dengan pembengkakan pada luka bekas potongan daun. Fenomena ini juga 

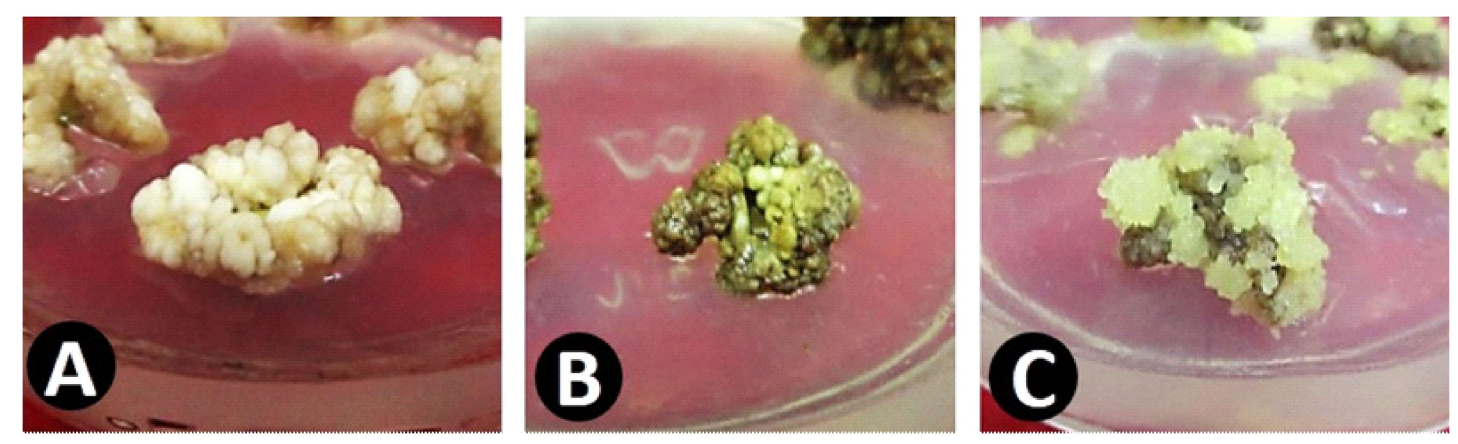

Gambar 3. Pembentukan kalus embriogenik pada media induksi kalus embriogenik(IKE). (a) Kalus putih dengan struktur kompak pada 8 MST (minggu setelah tanam) atau 4 MST di media IKE. (b) Pencoklatan kalus putih, (c) kalus embriogenik berwarna kekuningan dengan struktur remah muncul dari kalus berwarna coklat pada 13-16 MST.

dilaporkan oleh Ibrahim dan Hartati (2017) pada kultur in vitro tanaman kopi Robusta. Pada percobaan kami, pada perlakuan sitokinin saja (2-iP atau BA saja) dalam media IKP, kalus terbentuk terutama pada luka sayatan pada tulang-tulang daun (Gambar 2ab), sedangkan yang menggunakan campuran sitokinin dan auksin kalus-kalus terbentuk di seluruh luka bekas sayatan, tidak hanya di bekas sayatan pada tulang daun (Gambar 2cdef). Hal ini mungkin berhubungan dengan kandungan auksin dan sitokinin pada jaringan luka. Pada umumnya auksin dan sitokinin dibutuhkan untuk pembentukan kalus. Kondisi ini dipenuhi pada perlakuan campuran auksin dan sitokinin (2-iP dan 2,4D dan TDZ dan 2,4-D) yang mengakibatkan pembentukan kalus pada seluruh luka bekas sayatan (Gambar 2cdef) . Di lain pihak, penggunaan sitokinin saja tentunya hanya akan mengakibatkan pembentukan kalus pada tempat-tempat yang sudah mengandung auksin dan tempat-tempat tersebut diantaranya adalah tulang-tulang daun (Gambar 2ab), yang adalah jaringan transport, yang merupakan jaringan vaskuler yang terdiri atas xilem dan floem. Jaringan vaskuler sudah diketahui merupakan sarana transport jarak jauh fitohormon, termasuk auksin (Lacombe dan Achard, 2016; Kudo et al., 2010; Bishoppet al., 2011). Park et al. (2017) menyatakan bahwa salah satu mekanisme transport auksin dalam tanaman adalah dengan jalur-cepat, yaitu berupa transport pasif melalui pembuluh floem dari source ke sink. Jadi pembuluh floem selalu mengandung auksin, dan pembuluh floem merupakan bagian dari anatomi tulang daun.

Hasil kajian oleh Etienne et al. (2018) menunjukkan bahwa pemberian auksin dari luar tidak dibutuhkan untuk pembentukan kalus embriogenik dan multiplikasinya pada embriogenesis in vitro pada sebagian besar genotipe tanaman kopi Robusta. Untuk proses itu, ZPT dari luar yang dibutuhkan hanyalah sitokinin. Penggunaan sitokinin saja (yaitu benziladenin [BA]) sudah dilaporkan Ducos et al (2007) pada scaling up produksi bibit kopi Robusta melalui embriogenesis somatik.Pada penelitian kami ini, sitokinin saja (yaitu 2-iP atau BA) mampu menginduksi pembentukan kalus primer. Penggunaan sitokinin saja yang berupa 2-iP pada embriogenesis tanaman kopi 


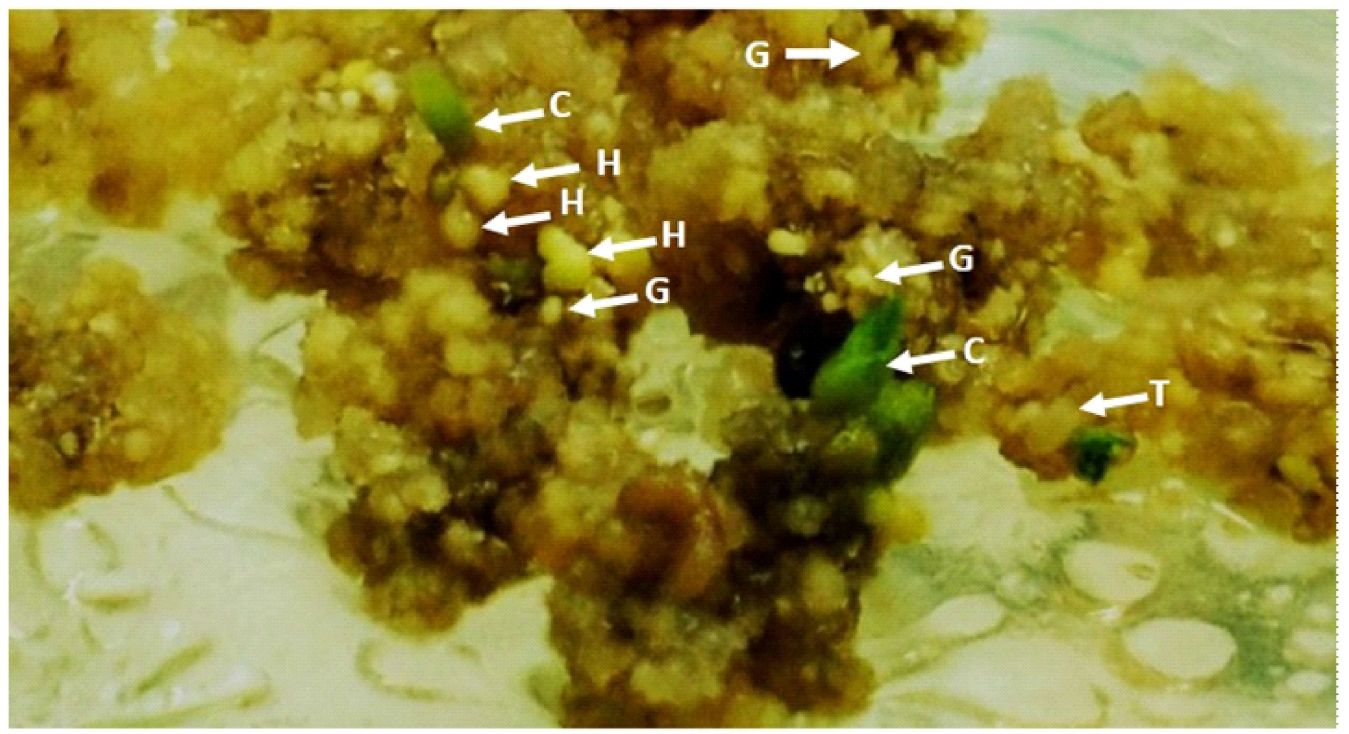

Gambar 4. Regenerasi embrio somatik kopi Robusta in vitro pada media regenerasi embrio somatik (RES). Tampak banyak embrio somatik pada tahap globular $(\mathrm{G})$, hati $(\mathrm{H})$, torpedo $(\mathrm{T})$, dan kotiledon $(\mathrm{C})$ (berwarna hijau) yangmulai menjadi kecambah (tanda panah).

in vitro juga dilaporkan oleh peneliti lain (Hatanaka et al., 1991).Namun demikian, dalam penelitian kami, penggunaan auksin bersama-sama dengan sitokinin mampu meningkatkan efektivitas pembentukan kalus primer. Dalam hal ini media induksi kalus yang mengandung 2-iP $1 \mathrm{mg} / \mathrm{l}$ dan 2,4-D 0,5 mg/1 atau 1 $\mathrm{mg} / \mathrm{l}$ adalah paling efektif di antara perlakuan yang dicobakan. Meskipun hasil ini mengkonfirmasi efektivitas penggunaan campuran ZPT tersebut yang dilaporkan oleh Samson et al. (2006), pada penelitian ini digunakan klon Komari, yang merupakan klon unggul kopi Robusta Lampung yang belum pernah dilaporkan. Di samping itu, perlakuan campuran ZPT tersebut ternyata tidak efektif untuk pembentukan kalus primer pada klon-klon kopi Robusta unggul Lampung lainnya (Hamiranti, 2019). Informasi ini sangat penting untuk pengembangan budidaya tanaman kopi di Lampung.

Pada penelitian kami ini, kalus primer dari semua perlakuan dapat berkembang menjadi kalus embriogenik pada waktu dikulturkan pada media IKE. Kalus-kalus embriogenik yang terbentuk dapat melalui perkembangan untuk membentuk embrio somatik pada waktu dikulturkan pada media regenerasi embrio somatik (RES) (Gambar 4).

\section{KESIMPULAN}

Dari hasil percobaan embriogenesis somatik kopi Robusta unggul Lampung cv. Komari, dapat disimpulkan sebagai berikut: (1) media yang mengandung masing-masing 2-iP 1 mg/l, BA 1 mg/l, TDZ $1 \mathrm{mg} / \mathrm{L}+2,4-\mathrm{D}$ 0,5 mg/L, atau TDZ $1 \mathrm{mg} / \mathrm{L}+$ 2,4-D $1 \mathrm{mg} / \mathrm{L}$ dapat menginduksi pembentukan kalus primer; (2) penambahan 2,4-D 0,5 atau $1 \mathrm{mg} / \mathrm{l}$ pada media yang mengandung 2-iP $1 \mathrm{mg} / 1$ menyebabkan peningkatan secara signifikan bobot basah kalus primer; dan (3) media yang mengandung campuran 2-iP $1 \mathrm{mg} /$ 
1 dan 2,4-D $0,5 \mathrm{mg} / 1$ atau 2,4-D $1 \mathrm{mg} / 1$ adalah penginduksi kalus primer paling efektif di antara perlakuan yang dicobakan.Kalus primer dapat berkembang menjadi kalus embriogenik pada media induksi kalus embriogenik, lalu kalus embriogenik dapat berkembang menjadi embrio somatik pada media regenerasi embrio somatik.

\section{DAFTAR PUSTAKA}

Arnold, S.V. 2008. Somatic embryogenesis. In E.F. George, M.A. Hall, and G.J. DeKLerk (Eds.) Plant Propagation by Tissue Culture. 3rd Edition. Vol 1. The Background. Springer. AA Dordrecht, The Netherlands.

Bishopp, A., S. Lehesranta, A.Vaten,H. Help, S. ElShowk, B. Scheres, K. Helariutta, A. Pekka Mahonen, H. Sakakibara, and Y. Helariutta. 2011. Phloem-transported cytokinin regulates polar auxin transport and maintains vascular pattern in the root meristem. Current Biology 21: 927-932.

Direktorat Jenderal Perkebunan, 2015. Statistika Perkebunan Indonesia: Kopi.

Ducos, J.P., G. Labbe, C. Lambot, and V. Pétiard. 2007. Pilot scale process for the production of pre-germinated somatic embryos ofselected robusta (Coffea canephora) clones. In vitro Cellular and Developmental Biology - Plant, 43(6):652-659.

Etienne, H., D. Breton, J. C. Breitler, B. Bertrand, E. Déchamp, R. Awada, P. Marraccini, S. Léran, E. Alpizar, C. Campa, P. Courte, F. Georget, andJ.P. Ducos. 2018. Coffee somatic embryogenesis: how did research, experience gained and innovations promote the commercial propagation of rlite clones from the two cultivated species?Front. Plant Sci. 9:1630.doi: 10.3389/fpls.2018.01630.

Hapsoro, D. dan Yusnita. 2018. Kultur Jaringan: Teori dan Praktik. Andi Publisher. Yogyakarta. 167 hal.

Hamiranti, R. 2019. Embriogenesis Somatik In Vitro Kopi Robusta (Coffea canephora Pierre ex Froehner) Klon Unggul Lokal Lampung. Thesis. Program Pascasarjana, Magister Agronomi, Fakultas Pertanian, Universitas Lampung. 52 hal.

Hartatri, D.F.S., S. Mawardi dan T. Wahyudi. 2016. Ekonomi Kopi, dalam: Kopi: Sejarah, Botani, Proses Produksi, Pengolahan, Produk Hilir dan Sistem Kemitraan (Editor: T. Wahyudi, Pujiyanto, Misnawi). Pusat Penelitian Kopi dan Kakao Indonesia. Gajah Mada University Press (hlm 1-18).

Hatanaka, T., O. Arakawa, T. Yasuda, N. Uchida, dan T. Yamaguchi. 1991. Effect of plant growth regulators on somatic embryogenesis in leaf cultures of Coffea canephora. Plant Cell Reports 10:179-182.

Ibrahim, M. S. D. dan R. S. Hartati. 2017. Peningkatan induksi kalus embriogenik dan konversi embrio somatik kopi robusta klon BP 308. Jurnal Tanaman Industri dan Penyegar 4 (3): 121132.

Kudo, T., T. Kiba, and H. Sakakibara. 2010. Metabolism and long-distancetranslocation of cytokinins. J. Integr. Plant Biol. 52, 53-60. 
Lacombe, B. and P. Achard. 2016. Long-distance transport of phytohormones through the plant vascular system. Current Opinion in Plant Biology 34:1-8.

Murashige T. and F. Skoog. 1962. A revised medium for rapid growth and bioassays with tobacco tissue cultures. Physiol. Plant. 15: 473-497.

Park, J., Y.Lee., E. Martinoia, and M. Geisler. 2017. Plant hormone transporters: what we know and what we would like to know. BMC Biology (2017) 15:93.DOI 10.1186/s12915-0170443-x

Samson, N.P., C. Campa, L. Le Gal, M. Noirot, G. Thomas, T. S. Lokeswari, dan A.de Kochko. 2006. Effect of primary culture medium composition on high frequency somatic embryogenesis in different Coffea species. Plant Cell Tiss Organ Cult 86:37-45.

USDA. 2016. Cofee: World Markets and Trade. USDAForeignAgricultural Service, December 2016 (http://www.fas.usda.gov/data/cofeeworld-markets-and-trade)

Worldatlas, 2019. Top Coffee Producing Countries. https://www.worldatlas.com. Diakses 12 Oktober 2019. 